\title{
Farmer rationality and the adoption of greening practices in Poland
}

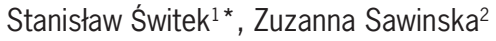 \\ 1Poznań University of Life Sciences/Institute of Zoology, \\ Wojska Polskiego, 71C - 60-625 - Poznań - Poland. \\ 2Poznań University of Life Sciences - Dept. of Agronomy, \\ Dojazd, 11 - 60-632 - Poznań - Poland. \\ *Corresponding author <switek@up.poznan.pl>
}

Edited by: Francesco Montemurro

\begin{abstract}
Common Agricultural Policy (CAP) reform in the European Union introduced a new element: greening. The aim of greening is to support the environment and create non-productive value in agriculture. The main element of greening is the Ecological Focus Area (EFA) meaning that a portion of farmland area has to be designed for environmental purposes. This article consists of an evaluatation of greening and its elements in the first year CAP reform has come into force. Surveys were used as a tool to gather information about farm characteristics, ways to meet greening requirements as well as the opinions of farmers as to changes in direct subsidies and greening obligations. The research was conducted in 2015 directly interviewing 290 farmers from the whole of Poland. The farmers interviewed lived in different parts of the country and had different size farms. Data was prepared with the use of spreadsheets and were analysed using the R statistical program and the "gmodel" and "vcd" statistical packages were used during the calculations. Polish farmers are against greening. Greening does not significantly change the way farmers run their farms. They choose the cheapest options of EFA which are usually not the best for the environment. Furthermore, farmers have to bear the cost of introducing the new elements themselves. Despite a high number of environmental and agricultural advantages offered by new farming methods, crop rotation and after-crop sowing duty, CAP reform is assessed in a negative light. As a result of negative opinions held by farmers due to the lack of subsidies, farmers may not continue greening practices in the future.

Keywords: CAP, EFA, agriculture, farm management, farmer survey
\end{abstract}

Received April 28, 2016

Accepted July 28, 2016 in their incomes (Koltun et al., 2015). Spatial diversity in agriculture requires selection of regions which will be subjected to constant review and assessment (Markuszewska, 2015). In this way, researchers will be able to better track data which will reflect geographical and historical differences. The aim of this study was to investigate the opinion of farmers about greening programs as well as practices that farmers have started to apply. Our aim was to observe how the opinions expressed by farmers are linked to both the size and location of farms.

\section{Materials and Methods}

The research was conducted in 2015 with the use of the questionnaire investigation method on 300 farmers from all over Poland. A total of 290 forms were correctly filled in. Ten forms did not contain information about the size of farm and were, consequently, rejected. The interviewed farmers ed lived not only in different parts of Poland and had different farm size but were of different ages with different levels of education. Surveys were conducted during training organized by agricultural companies and interviews were also conducted during the agricultural fair.

Surveys were collected from the four regions of Poland: northern (West Pomeranian region - 27 answers), southern (Lower Silesian, Opole and Silesian region - 47), central (Greater Poland, Lubusz and Kujavian-Pomeranian region - 120) and eastern (Lublin, Podkarpackie and Lesser Poland region - 96). The most widely represented region was central Poland from which $42 \%$ of the surveys were collected. The northern region was the least 
widely represented as only $9 \%$ of the survey was collected from there (Figure 1).

The biggest group was formed by farmers with farming areas greater than 100 ha - 83 questionnaires (29\%). The smallest group of farmers had farms smaller than 15 ha - 18 questionnaires (6\%) (Figure 2).

The survey was divided into three parts. The first part concerned farm characteristics, i.e., its size, localization, and possession of livestock. In the second part of the questionnaire farmers were asked about their opinion on greening and the impact that this policy had on their farms. Farmers were also asked about their attitudes to environmental protection and how greening changed this view. The third part of the questionnaire concerned the EFA (Ecological Focus Area). Farmers

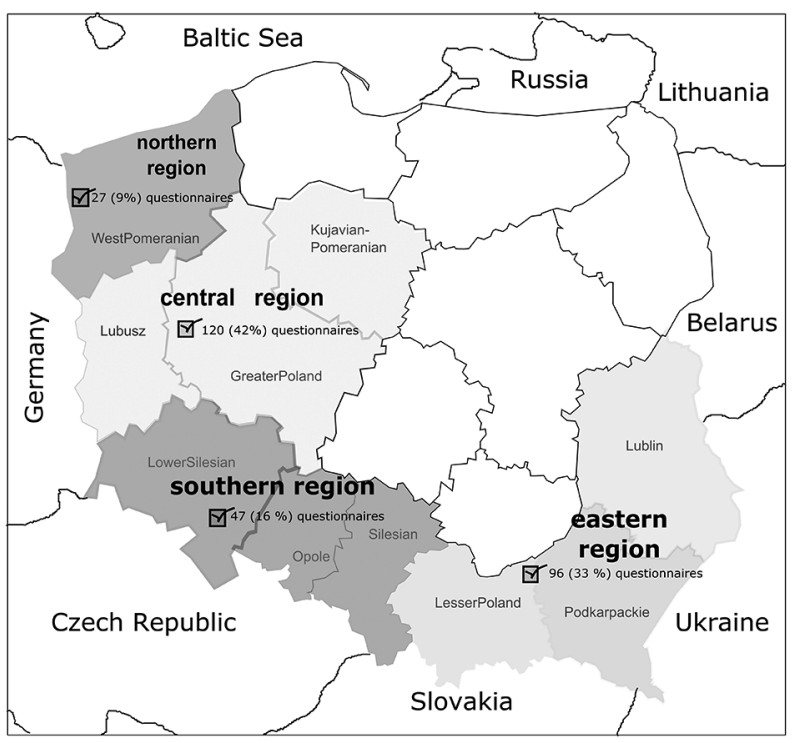

Figure 1 - Map of Poland and number of collected questionnaires from each region.

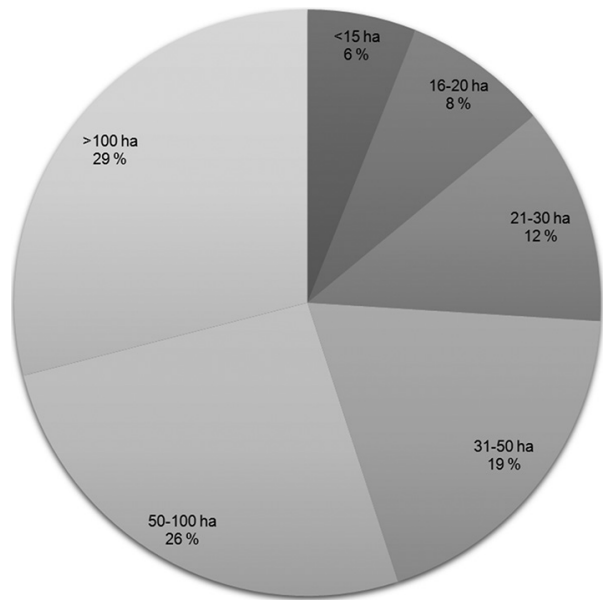

Figure 2 - Frequency of responses by different farm size. must dedicate $5 \%$ of their land to pro-environmental issues. This can be achieved by various methods. In the survey they were asked about the type of methods chosen and their impact on environmental protection. Importantly, according to new regulations, farms smaller than 15 hectares are exempt from EFA regulation. This group was also included in testing to observe if there were any improvements in the situation anyway on this kind of farm. There were close-ended questions in the survey and for most of the questions the answers were yes/no. A number of questions relating to the opinions of farmers had more answers to choose from e.g. very bad, bad, neutral. This resulted in well-completed questionnaires wherein a small number of responses gave reliable answers.

Data was prepared with the use of spreadsheets analysed by an " $\mathrm{R}$ " statistical program. " $\mathrm{R}$ " software is free and is used for statistical computing and graphics. It can also be extended via additional packages. In our analysis two of these packages were used, the aforementioned gmodels and vcd. Data had a categorizing character and two statistical tests i.e., Chi-Square Goodness of Fit Test and Cochran-Mantel-Haenszel, were used to analyze the data. With the use of these two tests, differences between the responses with various farm sizes and locations were checked. The $p$-values listed in the tables indicate how the response vary from one another. Values below 0.05 indicate significant differences between groups which signify different responses from farmers. When the $p$-value is closer to 1 the answers given are more equal in each group. This shows the unanimity of the opinions of farmers.

\section{Results}

Table 1 shows the results of a survey relating to the farmers: $33 \%$ of the farmers produced pigs, and $22 \%$ had dairy production, $49 \%$ of the farms surveyed in 2015 had livestock productions, $45 \%$ had participated in the past in agri-environmental programs, and $55 \%$ of the surveyed farmers' cultivated legumes. Another factor regulated by greening is crop rotation. If the farm is larger than 30 hectares 3 plant species have to be cultivated on the land. The main crop may not exceed $75 \%$ of the acreage, and the two majors cannot exceed $95 \%$. Farms with an area between 10 and 30 ha must be planted with a minimum of two plant species, and the area of the main species cannot exceed $75 \%$. In this case 56 $\%$ of the farmers surveyed had to change the surface of cultivated plants, and $46 \%$ were cultivating new plants. The new program brought with it a change in income for $48 \%$ of the farmers. While $58 \%$ of the farmers did not care more about the environment after greening implementation $57 \%$, nevertheless, believed that, thanks to greening, their farms are more pro-environmental.

Table 2 shows the opinion of farmers on the impact that greening may have on several factors. Bureaucracy is most commonly identified as the one factor 
Table 1 - Characteristics of farms participating in the survey and the actions that were taken in the first year of greening.

\begin{tabular}{|c|c|c|c|c|}
\hline & \multicolumn{2}{|c|}{$\begin{array}{l}\text { Confirms } \\
\text { response }\end{array}$} & \multicolumn{2}{|c|}{$\begin{array}{l}\text { Not confirms } \\
\text { response }\end{array}$} \\
\hline & \multicolumn{2}{|c|}{$\overline{\text { Amount Rate }}$} & \multicolumn{2}{|c|}{ Amount Rate } \\
\hline & & $\%$ & & $\%$ \\
\hline Pig productions in farm & 86 & 33 & 175 & 67 \\
\hline Cattle productions in farm & 54 & 22 & 189 & 78 \\
\hline Livestock productions in farm & 141 & 49 & 144 & 51 \\
\hline Participated in agri-environmental programs & 127 & 45 & 154 & 55 \\
\hline Cultivated on farm leguminous plants & 156 & 55 & 127 & 45 \\
\hline Changed the surface of cultivated plants & 145 & 56 & 116 & 4 \\
\hline Cultivated new plants on farm & 118 & 46 & 138 & 5 \\
\hline $\begin{array}{l}\text { Greater care for the environment due to } \\
\text { greening }\end{array}$ & 106 & 42 & 145 & \\
\hline Change the income due to greening & 124 & 48 & 133 & 5 \\
\hline Keeping farm more pro-environmental & 137 & 57 & 105 & 4 \\
\hline
\end{tabular}

Table 2 - Impact of greening on the various factors in the opinion of farmers'.

\begin{tabular}{|c|c|c|c|c|c|c|}
\hline & \multicolumn{2}{|c|}{ Increase } & \multicolumn{2}{|c|}{ Decrease } & \multicolumn{2}{|c|}{ No change } \\
\hline & Amount & Rate & Amount & Rate & Amount & Rate \\
\hline & & $\%$ & & $\%$ & & $\%$ \\
\hline Costs of production & 137 & 66 & 16 & 8 & 56 & 27 \\
\hline Crop yields & 82 & 50 & 20 & 12 & 62 & 38 \\
\hline Income on the farm & 38 & 25 & 40 & 26 & 75 & 49 \\
\hline Bureaucracy & 157 & 80 & 6 & 3 & 34 & 17 \\
\hline Value of the farm & 19 & 14 & 15 & 11 & 104 & 75 \\
\hline
\end{tabular}

which may rise because of greening. Only $17 \%$ of the farmers have a neutral opinion on this subject. The second factor indicated by farmers is the cost of production; $66 \%$ of the farmers claim that these costs are higher and in the opinion of $27 \%$ of the farmers the program has no impact on the cost. Most farmers $(75 \%)$ claim that greening will not affect the value of the farm; $14 \%$ of farmers believe that it can increase the value of the farm and $11 \%$ of them claim that it may lead to a lower value of a farm. In the opinion of $49 \%$ of the farmers, greening will have no impact on the amount of income of the farm. Activities e.g., crop rotation, sowing legume, catch crop cultivation within the greening may contribute to the growth of the crop. According to $50 \%$ of the farmers yield may increase; $12 \%$ believe that it will reverse the process.

To apply the greening farms must meet three requirements. The first one is crop rotation, second is the maintenance of permanent grassland, and the third is a $5 \%$ allocation of land to the Environmental Focus Area. The farm may have natural elements such as trees, ponds, and grassland but the vast majority of farms must also apply additional methods. These methods are listed in Table 3.

More than half of the farmers chose cultivation of catch crops $(39 \%)$ or cover crops $(12 \%) ; 30 \%$ of farmers cultivated leguminous crops and only $6 \%$ of the farmers decided to set aside lands. Of note, $2 \%$ did not have to
Table 3 - Percentage of farms choosing one of the available EFA (ecological focus area) methods and the reasons for their selection categorized by farm location.

\begin{tabular}{|c|c|c|c|c|c|}
\hline & \multicolumn{4}{|c|}{$\begin{array}{l}\text { Response rate depending on the } \\
\text { regions (\%) }\end{array}$} & \multirow[t]{2}{*}{ Poland } \\
\hline & Central & East & North & South & \\
\hline \multicolumn{6}{|c|}{ Methods } \\
\hline Cultivating catch crops & 43 & 31 & 20 & 59 & 39 \\
\hline Cultivating leguminous crops & 28 & 40 & 37 & 7 & 30 \\
\hline Cultivating cover crops & 15 & 8 & 15 & 9 & 12 \\
\hline Set aside field & 2 & 7 & 10 & 9 & 6 \\
\hline Forest border & 3 & 6 & 5 & 3 & 4 \\
\hline Buffer strips & 3 & 4 & 5 & 5 & 4 \\
\hline Forest area & 2 & 2 & 2 & 2 & 2 \\
\hline Hedges & 1 & 1 & 2 & 2 & 1 \\
\hline None of these & 2 & 1 & 5 & 5 & 2 \\
\hline \multicolumn{6}{|c|}{ Reasons for choice } \\
\hline Cheapest method & 22 & 15 & 21 & 26 & 20 \\
\hline Smallest effort & 17 & 17 & 15 & 23 & 18 \\
\hline Most cost-effective method & 11 & 15 & 9 & 8 & 12 \\
\hline Not absorbing area method & 26 & 23 & 21 & 24 & 24 \\
\hline Environmentally friendly method & 8 & 10 & 15 & 8 & 9 \\
\hline Positive impact on yield & 16 & 21 & 18 & 13 & 17 \\
\hline
\end{tabular}

take these actions to fulfill the requirement of the EFA. Due to their size, these farms were exempt from the obligation of greening or had enough natural elements in the environment. Growing catch crops was the most popular method of greening in the central and southern region. In the northern and eastern regions the cultivation of leguminous plants was the most popular. In the northern region $10 \%$ of the farmers set land aside. In the central region, farmers chose methods that do not cause loss of field space. For this reason, in the central region of Poland the least popular were for example, hedges, buffer strips and forest borders. It was observed that while choosing one or several greening practices farmers considered the economic factors (implementation costs). One of the main reasons is the cheapness of the method implemented $(20 \%)$ and the preservation of cultivated areas $(24 \%)$. Thus, cultivation of legumes and after-crops were dominant practices. The time that farmers needed to devote to a particular practice was important for $18 \%$ of the farmers. The potential influence of a method on crop yield was important for $17 \%$ of the farmers. The least important factor was the influence of a particular method on the environment $19 \%$ of the farmers). For farmers in the central region the most important reason when choosing the method is not to lose arable lands (26\%). The cheapness of the method is also essential $(22 \%)$. In the remaining regions these two factors were also the most important for farmers. While selecting the greening method the least important factor for most farmers was its impact on the environment. Only in the northern region of Poland did farmers claim that selection of environmentally friendly methods was an important factor (Table 3). 
Table 4 shows the methods and the reason for their use within the EFA framework, depending on the size of the farm. Regardless of farm size, in the mainpart, farmers chose the cultivation of secondary crops and legumes. Farms smaller than 15 ha were not required to take action within the framework of the EFA. A number of them have chosen, however, the cultivation of secondary crops and legumes. All farms, regardless of size, were less likely to choose the method of reasons relating to protection of the environment.

Table 5 shows what plants were planted as a catch crop. This was usually a mixture of various plants. Mustard plant was the most commonly chosen catch crop or cover crop (53\% and $53 \%$ ). Phacelia was the second of the most frequently chosen plants in catch crop practice (32\%). Of note, this plant was commonly sown together with a mustard plant. In catch crop farmers decided also to sow lupine (17\%), rye (15\%), oilseed rape (11\%), barley $(11 \%)$, oats $(9 \%)$ and peas $(8 \%)$. Serradella and cereals were selected by less than $6 \%$ of the farmers. Those of them who decided to choose cover crops, which need to be maintained until 01 Mar, placed mustard plant in first place (53\%). Oat (23\%), barley $(20 \%)$ and lupine $(15 \%)$ were also popular. Phacelia and oilseed rape were popular among approximately $13 \%$ of the farmers. 11 $\%$ of the winter cover crops were sown with peas and wheat (10\%). Additionally, vetch (6\%), and sunflowers (5\%) were sown.

The characteristics of farms and decisions made under the influence of greening are presented in Table 6. Columns show the percentage of farms, which correspond to the characteristics described. Different responses are shown in a column with $p$-value. Values less than 0.05 are noted as statistically different and $20-26$ $\%$ of farms, regardless of the surface, have cattle. In the case of swine, there is a trend to reduce the share of farms with animals and, concomitantly, to enlarge the cultivation area. Only $16 \%$ of farms with an area over 100 ha had pigs, while only $50 \%$ of the $16-20$ ha farms have these animals. Farms bigger than 100 hectares have the rarest animals (40\%). Farms with an area of between 50-100 ha were the main participants in agri-environmental schemes $(54 \%)$. The smallest farms with an area less than 20 ha were less likely to participate in the program. Farms of various sizes confirmed equally that the greening practice changed their income. The results fluctuated between $36 \%$ and $57 \%$. With the increase of arable land area farms had to change the area of cultivated plants to meet greening requirements and $69 \%$ of farms with arable land exceeding 100 hectares had to make changes in cultivation area. Small farms (less than $15 \mathrm{ha}$ ) were in the best situation but they are not directly affected by greening. Most farmers will choose the same greening methods in the following years. This suggests that the most popular may become catch crops and sandy leguminous crops. At the same time most farmers claim that they would not apply greening practices if there were subsidies for it.

Table 7 presents the opinions of farmers concerning greening and its consequences for the farm and the environment. It is dependent on the size of the farm. Numeric values indicate the percentage of farmers who gave a positive response and the $p$-value indicates the differences between groups. Most farmers agree that there is an increase in both bureaucracy and the cost of running farms. Along with the increase in the area of the farm, farmers often express a negative opinion on the diversity of the system of subsidies for farms of various sizes and $51 \%$ of the farmers with farms bigger than 100 hectares consider greening an unfair program.

Table 4 - Percentage of farms choosing one of the available EFA (ecological focus area) methods and the reasons for their selection categorized by farm size.

\begin{tabular}{|c|c|c|c|c|c|c|c|}
\hline & \multicolumn{6}{|c|}{ Response rate depending on the surface (\%) } & \multirow{2}{*}{ Poland } \\
\hline & 15 ha & 16-20 ha & 21-30 ha & $31-50$ ha & $50-100$ ha & 100 ha & \\
\hline \multicolumn{8}{|c|}{ Methods } \\
\hline Cultivating catch crops & 27 & 44 & 33 & 44 & 41 & 37 & 39 \\
\hline Cultivating leguminous crops & 20 & 32 & 33 & 32 & 31 & 28 & 30 \\
\hline Cultivating cover crops & 7 & 12 & 15 & 9 & 13 & 12 & 12 \\
\hline Set aside field & 0 & 8 & 6 & 4 & 7 & 5 & 6 \\
\hline Forest border & 13 & 4 & 2 & 2 & 3 & 7 & 4 \\
\hline Buffer strips & 7 & 0 & 2 & 3 & 4 & 5 & 4 \\
\hline Forest area & 0 & 0 & 2 & 4 & 1 & 3 & 2 \\
\hline Hedges & 0 & 0 & 2 & 0 & 1 & 2 & 1 \\
\hline None of these & 27 & 0 & 4 & 3 & 0 & 2 & 2 \\
\hline \multicolumn{8}{|c|}{ Reasons for choice } \\
\hline Cheapest method & 14 & 24 & 19 & 16 & 21 & 22 & 20 \\
\hline Smallest effort & 14 & 29 & 19 & 12 & 15 & 21 & 18 \\
\hline Most cost-effective method & 14 & 11 & 14 & 13 & 13 & 8 & 12 \\
\hline Not absorbing area method & 21 & 16 & 22 & 27 & 26 & 24 & 24 \\
\hline Environmentally friendly method & 14 & 5 & 7 & 11 & 8 & 10 & 9 \\
\hline Positive impact on yield & 21 & 16 & 19 & 21 & 18 & 14 & 17 \\
\hline
\end{tabular}


Farm size has also a noticeable effect on the estimation of the EFA's impact on biodiversity. Larger farmers have a more negative opinion. They also express more negative views on the reform of subsidies.

Table 8 shows the answers of farmers linked to farm location. Farms located in Greater Poland and $\mathrm{Ku}-$ javian-Pomeranian Voivodships (central region) usually focus on livestock. On the other hand, farms located in the northern and southern parts of Poland have the fewest livestock. Only every third farm has animals in these regions of Poland. In three regions of Poland there is a predominance of pig production and only in West Pomeranian Voivodship is cattle breeding dominant. As a part of greening obligations farmers decided to cultivate legumes. They were most commonly cultivated in the northern region of Poland and least frequently in southern Poland. Regardless of residence location, farmers evaluated the changes in agricultural policy in a similar manner.

The opinions of farmers on greening related to farm location are presented in Table 9. Farmers assessed the impact of greening on household finances in a different way. In the central and southern parts of the country most farmers believed that greening had a negative impact on their income. In the eastern region of Poland re-

Table 5 - Species of plants sown as a catch crop and cover crop.

\begin{tabular}{lccccc}
\hline $\mathrm{Nr}$ & Catch crop & Rate & $\mathrm{Nr}$ & Cover crop & Rate \\
\hline & Mustard & $\%$ & & & $\%$ \\
1 & 53 & 1 & Mustard & 53 \\
2 & Phacelia & 32 & 2 & Oat & 23 \\
3 & Lupine & 17 & 3 & Barley & 20 \\
4 & Rye & 15 & 4 & Lupin & 15 \\
5 & Oilseed & 11 & 5 & Phacelia & 13 \\
6 & Barley & 11 & 6 & Oilseed & 13 \\
7 & Oat & 9 & 7 & Peas & 11 \\
8 & Peas & 8 & 8 & Wheat & 10 \\
9 & Serradella & 6 & 9 & Vetch & 6 \\
10 & Cereals & 6 & 10 & Sunflower & 5 \\
\hline
\end{tabular}

spondents claimed that greening reform has not changed their situation. Farmers in the central and south of the country believe that the cultivation of leguminous plants is profitable. Farmers in northern and eastern Poland believe that it is profitable only with subsidies.

The highest number of negative opinions on the reform of the EU agricultural policy was found in the central region of Poland. In contrast, in the eastern part of Poland this reform is perceived as a positive one. In all regions of Poland a majority of farmers believe that actions taken within the framework of the EFA did not bring about an increase in biodiversity. In all regions, farmers noticed an increase in bureaucracy and in the opinions of the farmers the reform itself was neutral in terms of value to their farms.

The farmers interviewed gained knowledge about greening from many sources; $60 \%$ of them learned about greening from special training courses, $20 \%$ from the Internet, $9 \%$ from television and $7 \%$ from other farmers. Only $1 \%$ of the farmers interviewed had no knowledge of greening at all.

\section{Discussion}

The Common Agricultural Policy (CAP) is the oldest program of the European Union. Recent CAP reform was aimed at promoting protection of both the climate and the environment. Farmers receive a fraction of the subsidies for meeting greening requirements, i.e., for crop diversification or establishment of Ecological Focus Areas (EFA). Due to the new requirements now in force, the end of the first year of reform is a perfect time to investigate the opinions of farmers as well as to ascertain their greening practices and perspectives for the future. This article allows for the evaluation of greening in the first year of CAP reform coming into force and the results may be helpful in introducing changes into the program in subsequent years. In this article surveys were used as a tool to gather information about farm characteristics, ways to meet greening requirements and the

Table 6 - Characteristics of farms participating in the survey and the actions that were taken in the first year of greening categorized by farm size.

\begin{tabular}{|c|c|c|c|c|c|c|c|}
\hline & \multicolumn{6}{|c|}{ Confirmed response rate according to farms size (\%) } & \multirow{2}{*}{$p$-value } \\
\hline & $<15$ & 16-20 ha & $21-30$ ha & $31-50$ ha & $50-100$ & $>100$ ha & \\
\hline Livestock productions in farm & 50 & 55 & 44 & 61 & 53 & 40 & 0.2157 \\
\hline Swine productions in farm & 31 & 50 & 28 & 47 & 37 & 16 & 0.0032 \\
\hline Cattle productions in farm & 24 & 20 & 23 & 26 & 21 & 21 & 0.9800 \\
\hline Participated in agri-environmental programs & 17 & 27 & 43 & 49 & 54 & 47 & 0.0408 \\
\hline Cultivated in farm leguminous plants & 33 & 46 & 57 & 53 & 61 & 58 & 0.3252 \\
\hline Changed the surface of cultivated plants & 29 & 47 & 42 & 51 & 59 & 69 & 0.2080 \\
\hline Greater care for the environment due greening & 36 & 16 & 39 & 55 & 47 & 39 & 0.1491 \\
\hline Change in income due to greening & 43 & 57 & 35 & 45 & 50 & 53 & 0.5869 \\
\hline Keeping farm more pro-environmental & 36 & 63 & 58 & 67 & 61 & 47 & 0.1491 \\
\hline Farmers who would choose this same EFA practice next year & 90 & 80 & 85 & 90 & 91 & 88 & 0.7087 \\
\hline Applying EFA without payments & 44 & 17 & 39 & 43 & 22 & 36 & 0.1500 \\
\hline
\end{tabular}

$E F A=$ ecological focus area. 
Table 7 - Farmers' perspective on greening categorized by farm size.

\begin{tabular}{|c|c|c|c|c|c|c|c|}
\hline & \multicolumn{6}{|c|}{ Response rate depending on the farms size (\%) } & \multirow{2}{*}{$p$-value } \\
\hline & $<15$ ha & 16-20 ha & 21-30 ha & $31-50$ ha & $50-100$ ha & $>100$ ha & \\
\hline \multicolumn{8}{|c|}{ Leguminous cultivation in the opinion of farmers is } \\
\hline profitable & 56 & 2 & 37 & 29 & 32 & 37 & \\
\hline profitable only with payment & 44 & 47 & 33 & 49 & 45 & 48 & \\
\hline not profitable & 0 & 21 & 30 & 22 & 23 & 16 & 0.3933 \\
\hline \multicolumn{8}{|l|}{ Due to the new CAP farm } \\
\hline financial loss & 17 & 38 & 27 & 28 & 56 & 45 & \\
\hline no change & 50 & 52 & 44 & 52 & 26 & 40 & \\
\hline financial gain & 33 & 10 & 29 & 20 & 18 & 15 & 0.0097 \\
\hline \multicolumn{8}{|c|}{ Reform of the CAP by farmers is assessed as: } \\
\hline very negative & 0 & 10 & 9 & 7 & 16 & 22 & \\
\hline negative & 18 & 29 & 23 & 32 & 29 & 32 & \\
\hline neutral & 53 & 48 & 37 & 37 & 39 & 33 & \\
\hline good & 29 & 14 & 29 & 20 & 15 & 12 & \\
\hline very good & 0 & 0 & 3 & 4 & 1 & 0 & 0.2989 \\
\hline \multicolumn{8}{|c|}{ Financial support for small farms in the opinion of farmers is } \\
\hline unfair & 6 & 25 & 27 & 28 & 39 & 51 & \\
\hline no opinion & 28 & 35 & 32 & 47 & 44 & 42 & \\
\hline fair & 67 & 40 & 41 & 25 & 17 & 8 & 0.0001 \\
\hline \multicolumn{8}{|c|}{ Implementing EFA increases biodiversity } \\
\hline no & 6 & 11 & 14 & 10 & 17 & 24 & \\
\hline partial no & 31 & 42 & 23 & 42 & 37 & 42 & \\
\hline partial yes & 31 & 37 & 34 & 42 & 32 & 23 & \\
\hline yes & 31 & 11 & 29 & 6 & 14 & 11 & 0.0607 \\
\hline \multicolumn{8}{|l|}{ Production cost due to EFA is } \\
\hline lower & 0 & 13 & 16 & 6 & 5 & 8 & \\
\hline neutral & 38 & 19 & 16 & 34 & 27 & 28 & \\
\hline higher & 63 & 69 & 68 & 60 & 68 & 65 & 0.7300 \\
\hline \multicolumn{8}{|l|}{ Yields due to EFA are } \\
\hline lower & 13 & 0 & 8 & 7 & 21 & 13 & \\
\hline neutral & 38 & 42 & 46 & 36 & 40 & 30 & \\
\hline higher & 50 & 58 & 46 & 58 & 38 & 58 & 0.4814 \\
\hline \multicolumn{8}{|l|}{ Farmers' income due to EFA is } \\
\hline lower & 50 & 30 & 8 & 15 & 31 & 34 & \\
\hline neutral & 50 & 40 & 60 & 58 & 46 & 42 & \\
\hline higher & 0 & 30 & 32 & 27 & 23 & 24 & 0.3640 \\
\hline \multicolumn{8}{|l|}{ Bureaucracy due to EFA is } \\
\hline less & 24 & 0 & 4 & 6 & 3 & 2 & \\
\hline neutral & 38 & 25 & 19 & 18 & 17 & 12 & \\
\hline higher & 63 & 75 & 78 & 77 & 79 & 86 & 0.8297 \\
\hline \multicolumn{8}{|l|}{ Farm value due to EFA is } \\
\hline lower & 0 & 0 & 5 & 4 & 18 & 17 & \\
\hline neutral & 83 & 90 & 82 & 79 & 75 & 64 & \\
\hline higher & 17 & 10 & 14 & 17 & 8 & 19 & 0.4695 \\
\hline
\end{tabular}

CAP = Common Agricultural Policy; EFA = ecological focus area.

opinions of farmers on changes in direct subsidies and greening obligations. Information was grouped based on both farm size and location in Poland. In the past, land reforms affected farms to a variable extent (Maye et al., 2009). The data collected accentuate disparities between the opinions of farmers and the influence of the greening reform on farms depending on their size. Farmers who own farms bigger than 100 ha were against introducing greening reform in comparison to farmers who own smaller farms. Probably one may find additional conclusions in the publications of other authors (Walford, 2003; Cimino et al., 2015; Schulz et al., 2014). In Great Britain owners of big farms were also set against land reforms. Despite changes in farming systems imposed by different kinds of programs their attitude towards protection of the environment and extensive farming did not change (Walford, 2003). Research conducted on Italian farmers who own two types of farms (dedicated to the 
Table 8 - Characteristics of farms participating in the survey and the actions that were taken in the first year of greening categorized by farm location.

\begin{tabular}{|c|c|c|c|c|c|}
\hline & \multicolumn{4}{|c|}{$\begin{array}{l}\text { Confirmed response rate } \\
\text { according to farm size (\%) }\end{array}$} & \multirow[t]{2}{*}{$p$-value } \\
\hline & Central & East & North & South & \\
\hline Livestock production on farm & 59 & 49 & 35 & 33 & 0.0089 \\
\hline Pig production on farm & 36 & 36 & 17 & 29 & 0.3152 \\
\hline Cattle productions on farm & 30 & 17 & 24 & 14 & 0.1115 \\
\hline $\begin{array}{l}\text { Participated in agri-environmental } \\
\text { programs }\end{array}$ & 50 & 44 & 62 & 24 & 0.0076 \\
\hline $\begin{array}{l}\text { Cultivated leguminous plants on } \\
\text { farm }\end{array}$ & 55 & 64 & 70 & 29 & 0.0005 \\
\hline $\begin{array}{l}\text { Changed the surface of cultivated } \\
\text { plants }\end{array}$ & 59 & 52 & 50 & 56 & 0.7160 \\
\hline $\begin{array}{l}\text { Greater care for the environment } \\
\text { due to greening }\end{array}$ & 40 & 36 & 8 & 16 & 0.0066 \\
\hline Change in income due to greening & 43 & 51 & 56 & 50 & 0.6148 \\
\hline $\begin{array}{l}\text { Keeping farm more pro-environ- } \\
\text { mental }\end{array}$ & 64 & 55 & 50 & 47 & 0.2753 \\
\hline $\begin{array}{l}\text { Farmers who would choose this } \\
\text { same EFA practice next year }\end{array}$ & 89 & 84 & 91 & 95 & 0.4282 \\
\hline Applying EFA without payments & 39 & 32 & 29 & 20 & 0.3124 \\
\hline
\end{tabular}

EFA $=$ ecological focus area.

cultivation of either corn or wheat) showed that monoculture farms specialized in plant production are those that are mostly affected by reforms. Incomes decreased especially in regions of intensive farm production. This was forced by both changes in the area of cultivated plants as well as the introduction of less profitable plants. The study showed the different influences of new payment rules on farms. Determinant factors were farm location, specialization and economic strength (Cimino et al., 2015). German farmers think that greening will lead to increased bureaucracy and increased cost of running a farm. They also believe that greening itself will not lead to ecologic production. Farmers do believe that agriculture plays a major role in protecting the environment; $54 \%$ of German farmers support greening programs while only $14 \%$ of them are against it. German farmers who work only on farms full-time chose greening more often than part-time farmers (who have more than one job). The reason for this may be time and labor force savings (Schulz et al., 2014). Our research shows the opposite results. The bigger the farm land the probability of full-time job), the more negative the opinions farmers have on both reforms and practices connected with them. This may be caused by the greening method selected by farmers. In Poland a low number of farmers decided to set land aside. They chose more expensive and time-consuming methods, i.e., sowing of after-crops or legumes. The results of our research are in accordance with those published by Schulz (2014), Maye et al. (2009), Walford (2003) and Cimino et al. (2015). These publications showed that opinion on greening was dependent on the characteristics of both the farm and the farmers. Specialized and high productive farms were more willing to resign from greening as it generates the highest cost for them. Farmers who run their farms in central and southern regions of Poland (the most intensified agricultural regions) believe that greening will decrease their incomes $(23 \%$ central region vs $71 \%$ southern region). German and Polish farmers are interested in sowing legumes to meet greening requirements. This method was selected by $30 \%$ of the Polish farmers. Greening is a continuation and extension of agri-environmental projects whose elements were not compulsory until CAP reform. Research relating to these programs may be helpful in evaluating the current situation with regard to greening and the opinions of farmers on this subject. On the basis of economic factors which had influence on the decisions of farmers, Lastra-Bravo et al. (2015) showed that farmers whose income is dependent on agricultural production are less eager to join agri-environmental programs. They are more willing to participate in programs when their revenue shares from land are relatively low.

Defrancesco et al. (2008) shows that agriculture, with a high number of employed people, which is also dependent on farm income and is directed towards investments, is not so willing to take agri-environmental actions. Studies conducted on Polish farmers validate the findings of previously cited researchers. Farms with intensive agricultural production are commonly big farms and it is they that gave the most negative opinions. These farmers treat EFA as an expensive element of reforms which may contribute to lower economic performance as farm revenues will decrease. Interestingly, the improvement in environment condition may be of vital importance to farmers (Parolin et al., 2013). Kvakkestad et al. (2015) shows that for Norwegian farmers the maintenance of cultural and traditional values as well as keeping the land in good condition is extremely important. It is also essential for them to maximize incomes and production. Kvakkestad's results indicate that part-time farmers are positive about additional payments for creating public values. Farmers considered themselves to be, for the most part. food producers but the landscape and the creation of environmental products are also important to them. Kaluzna's research (2009) shows that there is a large discrepancy in ecological awareness amongst farmers. Farmers declare they have basic pro-environmental knowledge but at the same time they have a low level of knowledge about the interdependence between environment and agriculture. It is a reason why they do not fully use opportunities that European programs may give them. There is an incoherent and diversified awareness among farmers and a number of farmers run pro-environmental farms only because of special subsidies. Jaskulski and Jaskulska (2011) showed that the number of cultivated plants depends on the quality of arable lands. A greater number of plants is cultivated when the quality of arable lands is higher. There is a limited number of plants that can grow in poor quality soil so farmers should be interested in intercropping. Poland has medium quality lands. As the soil requirements for cultivating lupine are relatively low this plant 
Table 9 - Farmers perspective on greening categorized by farm location.

\begin{tabular}{|c|c|c|c|c|c|}
\hline & \multicolumn{4}{|c|}{ Farm location } & \multirow{2}{*}{$p$-value } \\
\hline & Central & East & North & South & \\
\hline \multicolumn{6}{|c|}{ Leguminous cultivation in the opinion of farmers is } \\
\hline profitable & 44 & 30 & 22 & 55 & \\
\hline profitable only with payment & 43 & 40 & 61 & 63 & \\
\hline not profitable & 13 & 29 & 17 & 5 & 0.0258 \\
\hline \multicolumn{6}{|l|}{ Due to the new CAP farm } \\
\hline financial loss & 51 & 19 & 40 & 57 & \\
\hline no change & 35 & 52 & 40 & 32 & \\
\hline financial gain & 14 & 30 & 20 & 11 & 0.0001 \\
\hline \multicolumn{6}{|c|}{ Reform of the CAP by farmers is assessed as } \\
\hline very negative & 19 & 6 & 12 & 18 & \\
\hline negative & 31 & 22 & 35 & 35 & \\
\hline neutral & 31 & 48 & 42 & 33 & \\
\hline good & 17 & 23 & 8 & 13 & \\
\hline very good & 1 & 1 & 4 & 2 & 0.0899 \\
\hline \multicolumn{6}{|c|}{ Financial support for small farms in the opinion of farmers is } \\
\hline unfair & 38 & 38 & 24 & 30 & \\
\hline no opinion & 44 & 38 & 36 & 44 & \\
\hline fair & 18 & 25 & 40 & 26 & 0.3515 \\
\hline \multicolumn{6}{|c|}{ Implementing EFA increases biodiversity } \\
\hline no & 18 & 15 & 8 & 21 & \\
\hline partial no & 33 & 41 & 44 & 37 & \\
\hline partial yes & 33 & 37 & 28 & 21 & \\
\hline yes & 16 & 8 & 20 & 21 & 0.3695 \\
\hline \multicolumn{6}{|l|}{ Production due to EFA is } \\
\hline lower & 6 & 8 & 17 & 7 & \\
\hline neutral & 23 & 41 & 28 & 0 & \\
\hline higher & 71 & 52 & 56 & 93 & 0.0010 \\
\hline \multicolumn{6}{|l|}{ Yields due to EFA are } \\
\hline lower & 15 & 9 & 27 & 5 & \\
\hline neutral & 25 & 44 & 53 & 37 & \\
\hline higher & 60 & 47 & 20 & 58 & 0.0477 \\
\hline \multicolumn{6}{|l|}{ Farmers' income due to EFA is } \\
\hline lower & 23 & 15 & 50 & 71 & \\
\hline neutral & 47 & 56 & 50 & 14 & \\
\hline higher & 30 & 28 & 0 & 14 & 0.0001 \\
\hline \multicolumn{6}{|l|}{ Bureaucracy due to EFA is } \\
\hline less & 3 & 1 & 12 & 5 & \\
\hline neutral & 11 & 21 & 29 & 18 & \\
\hline higher & 87 & 78 & 59 & 77 & 0.1020 \\
\hline \multicolumn{6}{|l|}{ Farm value due to EFA is } \\
\hline lower & 9 & 7 & 15 & 29 & \\
\hline neutral & 63 & 87 & 77 & 57 & \\
\hline higher & 28 & 6 & 8 & 14 & 0.0076 \\
\hline
\end{tabular}

$\mathrm{CAP}=$ Common Agricultural Policy; EFA = ecological focus area.

was cultivated by the majority of farmers interviewed. To improve the soil structure and fulfill greening duties, farmers chose winter intercrops (12\%), stubble intercrops $(38 \%)$ or legumes (30\%). This way of farming may contribute to soil quality improvements not only by reducing wind and water erosion but by also enriching the soil with organic matter. Greater Poland and Kujavian-Pomeranian Voivodships (provinces) have the largest share of arable lands. These voivodships have the high- est value of production resources per 1 ha, a high share of meliorated lands and a high number of cattle and livestock per 100 ha. West Pomeranian and Lower Silesian Voivodships are characterized by a low number of farm animals. Their production potential per 1 ha is also low. The Lublin and Podkarpackie regions have the lowest production potential. They are influenced by the average size of farms, small share of meliorated lands as well as animal headcount which is below the national average 
(Karwat-Woźniak, 2011; Czyzewski and Brelik, 2014). Similar data are shown in our research. Farms located in Greater Poland and the Kujavian-Pomeranian region have animals more often than farms located in other regions of Poland. In 2015 the lowest number of animals was kept in farms located in the northern and southern regions of Poland According to the Central Statistical Office (CSO, 2015), in 2014, 16.3 out of 31.3 million ha (total area of Poland) were taken up by farms and $72 \%$ of agricultural lands were sown. Land set aside comprised $3 \%$ and permanent pastures and meadows $21 \% ; 2 \%$ of lands were used for cultivation of permanent corps. The majority of sown lands $(72 \%)$ were used to cultivate cereals (CSO, 2015).

The farmers interviewed used legumes in aftercrop sowing only to a small extent. Intercrop cultivation was not so commonly used as it entails additional cost caused by, items such as seed acquisition, labour input, fuel, and extra agrotechnical practices. When the humidity of soil is insufficient after-crop plants may immobilize minerals and further reduce water resources for succeeding crops. Subsidies are implemented to cover additional costs and are incentives to start sowing after-crops (Lemoine et al., 2007). After-crop cultivation leads to lower loss of nitrogen from the soil and also allows the nitrogen content in the soil to increase with the use of legumes which absorb atmospheric nitrogen (Askegaard and Eriksen, 2007). Changes in the management system as well as increases in the after-crop growing area also have an impact on birds. In this case winter after-crop cultivation is a better solution than leaving fields plowed for the winter. Importantly, birds will benefit the most from overwinter stubbles. Aftercrop sowing, especially the cultivation of legumes, may contribute to increasing the crop yield of a subsequent plant. It may be a way to fight against the negative consequences of cereal monoculture as organic matter will be delivered to the soil (Wilczewski et al., 2015). The aim of after-cropping is to keep the land covered with plants up to the time when the main plants will be cultivated.

The goal of after-crop cultivation is also to prevent soil erosion and its long-term cultivation may increase the amount of organic matter in the soil. In Polish climate conditions plants sown in the winter (after collection of the main plants) are destroyed by frost. To produce a higher number of biomass, plants need to be sown earlier when soil temperature, humidity and access to sunlight is higher (Sauvé et al., 1998). Van Herzele et al. (2013) shows that money plays the key role in agri-environmental programs. The packets that require low investments and little work were the most important for farmers. When choosing the method to fulfil greening duty, Polish farmers were focused on minimizing the loss of cultivated area which may in turn lead to loss of crop yield. That is why they chose more timeconsuming variants, such as the sowing of intercrops or legumes. Importantly, they did not decide to set aside land. The opinions and decisions of farmers are made not only on the basis of farm type, environmental conditions and economic strength but also on individual preferences, situation and experience. Thus, it is really difficult to model farms based on statistical data only. The same farms may have different approaches to land reform which may depend on the individual preference of farmers (Edward-Jones, 2006). Survey data will never show the whole complexity of the situation but may shed light on it and pinpoint the most important problems. On the basis of our research it was shown that despite a high number of environmental advantages that new farming methods, crop rotation and after-crop sowing duty can offer, CAP reform is assessed in a negative ljght. This can be observed especially among farmers who own big farms. Their negative opinions imply that CAP reform directed to support smaller farmers and promote environment protection is a good approach. As a result of negative opinions among farmers in the case of lack of subsidies farmers may not continue EFA practices in the future.

\section{Conclusions}

Farmers evaluate CAP reform in a different way. Those who own farms smaller than 15 ha are mostly neutral to agricultural policy and its changes. Farmers who own 100 ha farms expressed mostly negative or bad opinions. Only $14 \%$ of farmers in this group has a positive opinion on CAP reform. The bigger the farm the farmers have, the more unjust it is for them to exempt small farms from greening obligations. Increases in biodiversity and support ecosystem services such as development and existence of beneficial insects are the main assumptions of new direct payment rules. In the opinion of farmers, changes implemented will not lead to increases in biodiversity but may lead to an increase in cost. Despite their negative opinions, farmers also see the positive side of methods used in the Ecological Focus Area (EFA) and $50 \%$ of them believe that these methods may contribute to higher crop yield. More than 50 $\%$ of farmers think that greening leads to more pro-environmental farms. Agricultural policy has a very large impact on agriculture and the environment and selection of appropriate method and financial incentive may result in increased biodiversity in agricultural areas. On the other hand, it does not actually discourage farmers from using tools. If they are carried out badly, they do not bring out the desired effects.

Lack of knowledge of farmers of the positive effects of greening on the environment and their farms makes them choose the least labor-intensive as well as the least expensive practices.

\section{Acknowledgement}

This research was funded by the European Union as part of the FP7 project LIBERATION (grant 311781). 


\section{References}

Askegaard, M.; Eriksen, J. 2007. Growth of legume and nonlegume catch crops and residua- $\mathrm{N}$ effects in spring barley on coarse sand. Journal of Plant Nutrition and Soil Science 170: 773-780.

Boulanger, P.; Philippidis, G. 2015. The EU budget battle: assessing the trade and welfare impacts of CAP budgetary reform. Food Policy 51: 119-130.

Cimino, O.; Henke, R.; Vanni, F. 2015. The effects of CAP greening on specialised arable farms in Italy. New Medit 14: 22-31.

Cortignani, R.; Dono, G. 2015. Simulation of the impact of greening measures in an agricultural area of the southern Italy. Land Use Policy 48: 525-533.

Central Statistical Office [CSO]. 2015. Land use and sown area in 2014. Central Statistical Office Warsaw, Warsaw, Poland. p. $1-49$.

Czyzewski, B.; Brelik, A. 2014. Sustainable development of agriculture: case of Poland. Annals of the Polish Association of Agricultural and Agribusiness Economists 16: 38-43.

Defrancesco, E.; Gatto, P.; Runge, F.; Trestini, S. 2008. Factors affecting farmers' participation in agri-environmental measures: a northern Italian perspective. Journal of Agricultural Economics 59: 114-131.

Edward-Jones, G. 2006. Modelling farmer decision-making: concepts, progress and challenges. Animal Science 82: 783790.

Erjavec, K.; Erjavec, E. 2015. "Greening the CAP" - Just a fashionable justification? A discourse analysis of the 2014-2020 CAP reform documents. Food Policy 51: 53-62.

Jaskulski, D.; Jaskulska, I. 2011. Diversity and dominance of crop plantations in the agroecosystems of the Kujawy and Pomorze region in Poland. Acta Agriculturae Scandinavica. Section B. Soil \& Plant Science 61: 633-640.

Kaluzna, H. 2009. Ecological awareness of farmers and the sustainable development of agriculture $=$ Świadomość ekologiczna rolników, a zrównoważony rozwój rolnictwa. Journal of Agribusiness and Rural Development 3: 63-71 (in Polish, with abstract in English).

Kapusta, F. 2015. Common agricultural policy of the European union and the changes in Polish agriculture. Acta Scientiarum Polonorum. Oeconomia 14: 47-54.

Karwat-Woźniak, B. 2011. Regional differentiation in the socioeconomic development conditions of the agriculture in Poland. Economics \& Sociology 4: 11-25.

Koltun, M.; Kocira, S.; Krzysiak, Z.; Cwiklinska, M.; Kocira, A.; Koszel, M. 2015. Economic size and developmental possibilities of chosen family farms in Poland. Agriculture and Agricultural Science Procedia 7: 113-118.

Kvakkestad, V.; Rorstad, P.K.; Vatn, A. 2015. Norwegian farmers' perspectives on agriculture and agricultural payments: between productivism and cultural landscapes. Land Use Policy 42: 8392.

Lastra-Bravo, X.B.; Hubbard, C.; Garrod, G.; Tolon-Becerra, A. 2015. What drives farmers' participation in EU agrienvironmental schemes? Results from a qualitative metaanalysis. Environmental Science \& Policy 54: 1-9.
Lemoine, M.L.; Civello, P.M.; Martinez, G.A.; Chaves, A.R. 2007. Influence of postharvest UV-C treatment on refrigerated storage of minimally processed broccoli (Brassica oleracea var. Italica). Journal of the Science of Food and Agriculture 87: 1132-1139.

Markuszewska, I. 2015. Intensification of extensification of polish agriculture? In searching of directions of changes. A case study: the northwestern region of Poland. Journal of Agribusiness and Rural Development 1: 67-73.

Matthews, K.B.; Buchan, K.; Miller, D.G.; Towers, W. 2013. Reforming the CAP- With area-based payments, who wins and who loses? Land Use Policy 31: 209-222.

Maye, D.; Ilbery, B.; Watts, D. 2009. Farm diversification, tenancy and CAP reform: results from a survey of tenant farmers in England. Journal of Rural Studies 25: 333-342.

Parolin, P.; Bresch, C.; Poncet, C.; Desneux, N. 2013. Introducing the term "biocontrol plants" for integrated pest management. Scientia Agricola 71: 77-80.

Sauvé, S.; Dumestre, A.; McBride, M.; Hendershot, W. 1998. Cover crop and soil quality interactions in agroecosystems. Journal of Soil and Water Conservation 53: 224-229.

Schulz, N.; Breustedt, G.; Latacz-Lohmann, U. 2014. Assessing farmers' willingness to accept "greening": insights from a discrete choice experiment in Germany. Journal of Agricultural Economics 65: 26-48.

Solazzo, R.; Donati, M.; Arfini, F. 2015. Cap towards 2020 and the cost of political choices: the case of Emilia-Romagna region. Land Use Policy 48: 575-587.

Sutcliffe, L.M.E.; Batary, P.; Kormann, U.; Baldi, A.; Dicks, L.V.; Herzon, I.; Kleijn, D.; Tryjanowski, P.; Apostolova, I.; Arlettaz, R.; Aunins, A.; Aviron, S.; Balezentiene, L.; Fischer, C.; Halada, L.; Hartel, T.; Helm, A.; Hristov, I.; Jelaska, S.D.; Kaligaric, M.; Kamp, J.; Klimek, S.; Koorberg, P.; Kostiukova, J.; KovacsHostyanszki, A.; Kuemmerle, T.; Leuschner, C.; Lindborg, R.; Loos, J.; Macchierini, S.; Marja, R.; Mathe, O.; Paulini, I.; Proença, V.; Rey-Benayas, J.; Sans, F.X.; Seifert, C.; Stalenga, J.; Timaeus, J.; Torok, P.; van Swaay, C.; Viik, E.; Tscharntke, T. 2015. Harnessing the biodiversity value of Central and Eastern European farmland. Diversity and Distribution 21: 722-730.

Tryjanowski, P.; Hartel, T.; Baldi, A.; Szyma ski, P.; Tobolka, M.; Herzon, I.; Goławski, A.; Konvicka, M.; Hromada, M.; Jerzak, L.; Kujawa, K.; Lenda, M.; Orłowski, G.; Panek, M.; Skórka, P.; Sparks, T.S.; Tworek, S.; Wuczynski, A.; Zmihorski, M. 2011. Conservation of farmland birds faces different challenges in Western and Central-Eastern Europe. Acta Ornithologica 46: 1-12.

Van Herzele, A.; Gobin, A.; Van Gossum, P.; Acosta, L.; Waas, T.; Dendoncker, N.; Frahan, B.H. 2013. Effort for money? Farmers' rationale for participation in agri-environment measures with different implementation complexity. Journal of Environmental Management 131: 110-120.

Walford, N. 2003. Productivism is allegedly dead, long live productivism. Evidence of continued productivist attitudes and decision-making in South-East England. Journal of Rural Studies 19: 491-502.

Wilczewski, E.; Piotrowska-Długosz, A.; Lemanczyk, G. 2015. Properties of Luvisol and spring barley yield as affected by peas as a catch crop. Zemdirbyste-Agriculture 102: 23-30. 